\section{(C) Р. Сильверман}

Государственный Нью-Йоркский Университет;

Университет усовершенствования врачей, Нью-Йорк

\section{НЕЙРОСОНОЛОГИЯ РАЗВИВАЮЩЕГОСЯ МОЗГА ПЛОДА: АНАТОМИЧЕСКАЯ И КЛИНИЧЕСКАЯ КОРРЕЛЯЦИЯ В НОРМЕ И ПРИ ПАТОЛОГИИ}

Эта лекция начинается с дискуссии, посвященной развитию мозга плода. Мы рассмотрим развитие нейронов и корреляцию этих процессов с клиническими проявлениями во всех триместрах беременности. Знание механизмов развития мозга плода в первом триместре является своеобразным окном, позволяющим заглянуть в будущее для диагностики возможных аномалий плода.

Будут рассмотрены данные МРТ и КТ с соответствующей интерпретацией и взаимной интеграцией изображений. Наиболее часто встречающиеся аномалии ЦНС будут представлены и обсуждены с учетом их проявлений и динамических изменений в зависимости от срока беременности. Редко встречающиеся аномалии будут рассматриваться особенно внимательно, с подробным описанием ключевых моментов их диагностики.

Также в деталях будут рассмотрены ограничения возможностей ультразвуковой диагностики определенных аномалий ЦНС, как со стороны плода, так и со стороны беременной.

В лекции будут представлены основные ориентиры и алгоритмы при оценке сонографических изображений для того, чтобы специалисты могли усовершенствовать свои знания по нейросонографии в случае патологии и улучшить качество диагностики.

\title{
NEUROSONOLOGY OF THE DEVELOPING FETAL BRAIN: ANATOMIC AND CLINICAL CORRELATES OF DISEASE
}

\section{Robert K. Silverman}

- Summary: This lecture will begin by discussing the development of the fetal brain. We will look at the neuronal development with clinical correlates in all trimesters of pregnancy. Discussion of the advantages of looking at the developing fetal brain in the first trimester of pregnancy as a window into the detection of fetal anomalies will be discussed. Integration with MRI and CT imaging will be interspersed with sonographic discussion and interpretation. Common fetal CNS abnormalities will be outlined and their evolution during advancing gestation will be reviewed. Less common defects will be discussed with attention to the clues in imaging that make their diagnosis easier. The limitations of ultrasound imaging for certain CNS anomalies will be outlined in detail. This will include both fetal as well as maternal limitations. Tips and options for sonographic imaging will be interspersed within the lecture to allow the participant several options for imaging fetal anomalies with neurosonography and improving their diagnostic accuracy. 